\title{
Synthesis of spiroannulated and 3-arylated 1,2,4-trioxanes from mesitylol and methyl 4-hydroxy- tiglate by photooxygenation and peroxyacetalization
}

\author{
Axel G. Griesbeck ${ }^{*}$, Lars-Oliver Höinck and Jörg M. Neudörfl
}

\section{Full Research Paper}

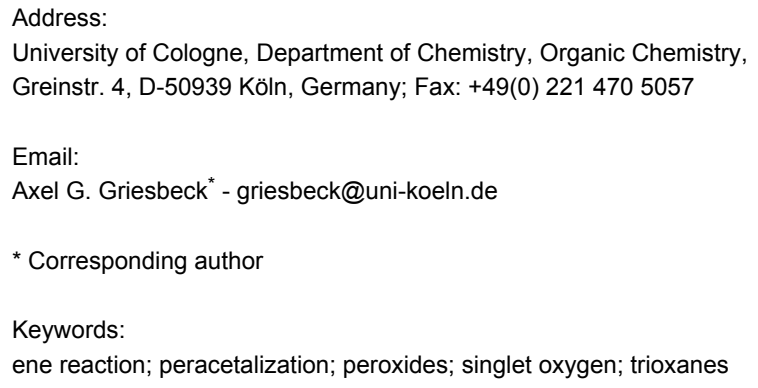

Beilstein J. Org. Chem. 2010, 6, No. 61. doi:10.3762/bjoc.6.61

Received: 13 April 2010

Accepted: 18 May 2010

Published: 07 June 2010

Associate Editor: J. Murphy

() 2010 Griesbeck et al; licensee Beilstein-Institut. License and terms: see end of document.

\begin{abstract}
Cycloalkanones were utilized in the Lewis acid catalyzed peroxyacetalization of ß-hydroperoxy homoallylic alcohols (prepared by the ene reaction of the allylic alcohols mesitylol and methyl 4-hydroxytiglate, respectively, with singlet oxygen) to give spiroannulated 1,2,4-trioxanes $\mathbf{5 a}-\mathbf{5 e}$ and $\mathbf{9 a}-\mathbf{9 e}$, respectively. A second series of 3-arylated trioxanes $\mathbf{1 0 a}-\mathbf{1 0 h}$, that are available from the hydroperoxy alcohol 4 and benzaldehyde derivatives, was investigated by X-ray crystallography.
\end{abstract}

\section{Introduction}

The antimalaria-active molecule artemisinin (1) is a naturally occurring sesquiterpene peroxide with remarkable pharmacological properties. Hydrophilic as well as lipophilic derivatives have been prepared from artemisinin and show improved antimalarial properties and better bioavailabilities [1-5]. In recent years, additional medicinal properties of artemisinin and the water soluble artesunates have been discovered such as activities against several cancer cell lines, schistosomiasis and antiviral properties [6,7]. The introduction of substituents into the central peroxide ring system as well as further ring annulation are straightforward approaches for the preparation of other active derivatives which might show promise in overcoming the forthcoming problem of artemisinin resistance [8]. From a synthetic point of view, the preparation of the pharmacophore, the central 1,2,4-trioxane ring system, is possible by a number of strategies $[9,10]$. We, for example, have previously reported the use of the singlet oxygen ene reaction of allylic alcohols as a route to $\beta$-hydroperoxy alcohols that can be transformed into 1,2,4-trioxanes by reaction with carbonyl compounds in the presence of Lewis acids [11]. This approach leads to simple cyclic peroxides (e.g. 2) which in some cases show similar antimalarial effects as the natural compound (Figure 1) [12]. An apparently useful structural feature is a large 3,3-spirofused hydrophobic group. The adamantane skeleton is a unique motif in other cyclic peroxides with antimalarial activities $[13,14]$ which additionally exhibit other remarkable pharmaceutical properties [15-17]. In this publication we report the use of the alcohols 3 and $\mathbf{6}$ to explore further the synthetic approach to spirocyclic fused 1,2,4-trioxanes with a series of other spirofused ring structures. 

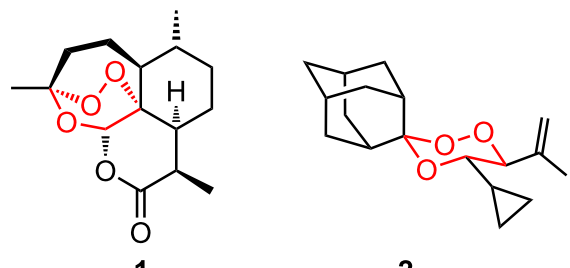

2

Figure 1: Antimalaria active natural artemisinin 1 and the spirobicyclic 1,2,4-trioxane derivative 2 show the same in vitro activity.

\section{Results and Discussion}

\section{3,3-Spiroannulated 1,2,4-trioxanes}

The photooxygenation reactions via sensitization of triplet oxygen with meso-tetraphenylporphyrin (TPP) were performed in polystyrene beads under solvent-free conditions (Scheme 1) $[18,19]$. Numerous applications of the hydroperoxides 4 and $\mathbf{7}$, that result from the singlet oxygen ene reactions, have already been reported $[20,21]$. In context with our work on bis-peroxide synthesis from bifunctional ketones [22], we have also studied the peroxyacetalization of the allylic hydroperoxide 7 with the bifunctional cyclohexane-1,4-dione (CHD, Scheme 2). In this case, one equivalent of the diketone gave the monoadduct $9 \mathrm{c}$ in $20 \%$ yield.

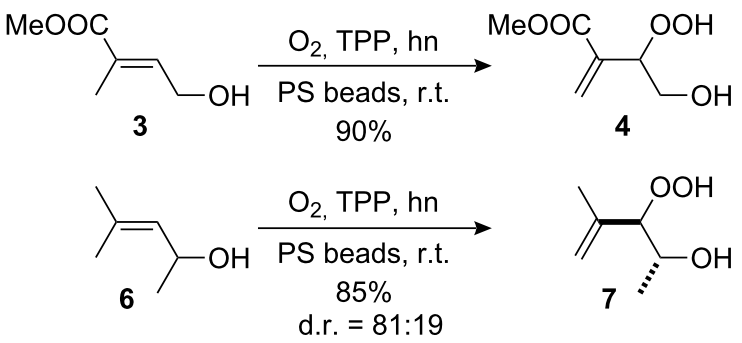

Scheme 1: Singlet oxygen ene reaction of methyl 4-hydroxytiglate (3) and mesitylol (6) under solid-phase conditions.

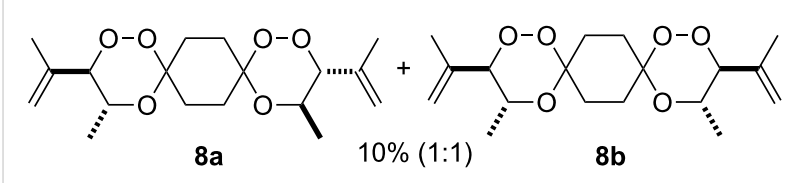

Scheme 2: 1,2,4-trioxane $9 \mathbf{c}$ and bis-trioxane $\mathbf{8 a}, \mathbf{b}$ formation from the bifunctional cyclohexa-1,4-dione.

Table 1: 3,3-Spiroannulated 1,2,4-trioxanes by photooxygenation and peroxyacetalization. ${ }^{a}$

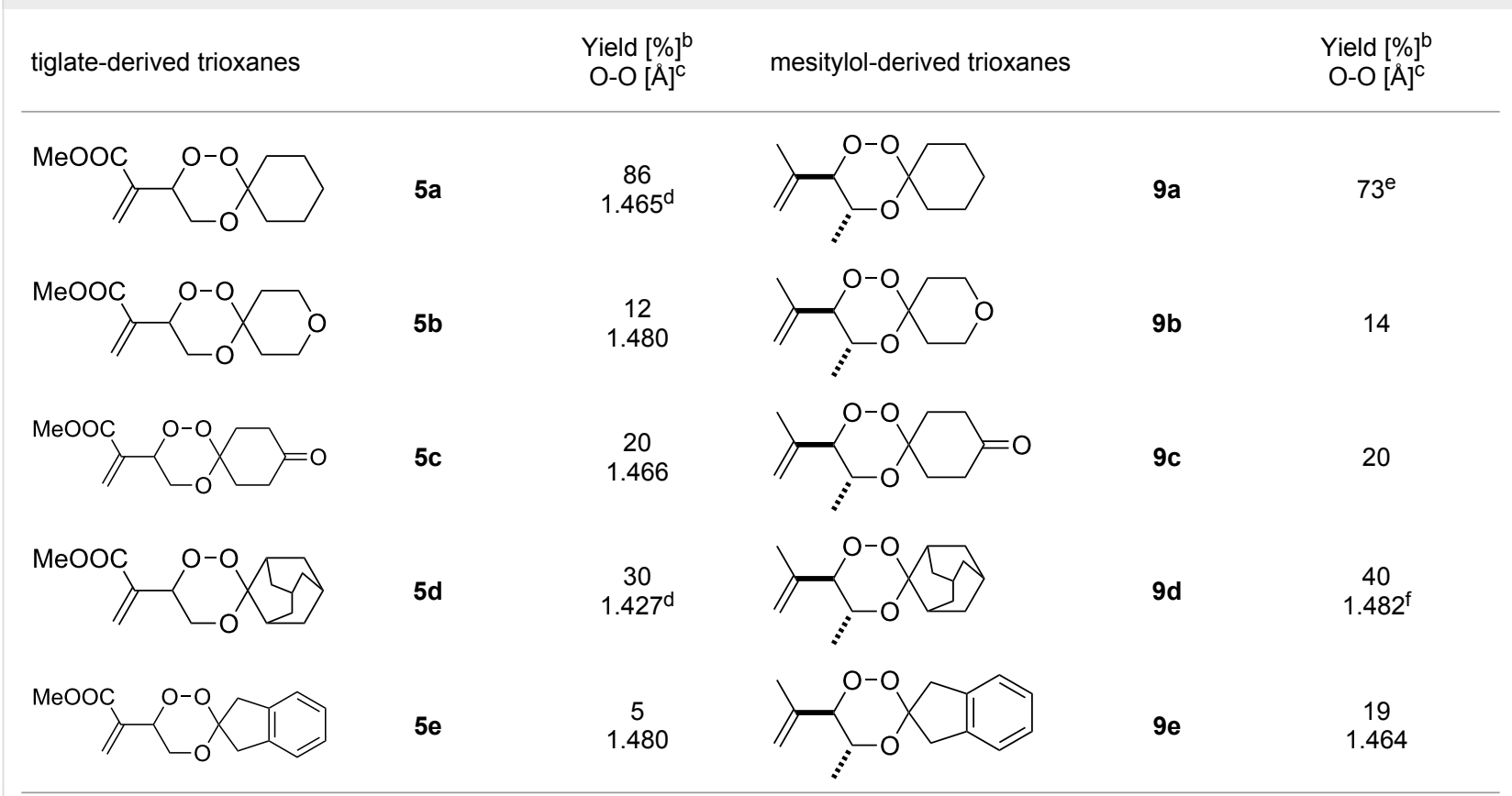

aStandard reaction conditions: substrate $\left(2 \mathrm{mmol}, 4 \times 10^{-2} \mathrm{M}\right), \mathrm{CCl}_{4}(50 \mathrm{~mL})$, meso-tetraphenylporphyrin $\left(0.01 \mathrm{mmol}, 2 \times 10^{-4} \mathrm{M}\right)$, r.t., $10 \mathrm{~h}$; then addition of a solution of the carbonyl compound $(2.5 \mathrm{mmol})$ in $\mathrm{CH}_{2} \mathrm{Cl}_{2}(10 \mathrm{~mL}), 0{ }^{\circ} \mathrm{C}, 3 \mathrm{~h}$. bYields of per-oxyacetalization. ${ }^{\mathrm{c}} \mathrm{From} \mathrm{X}$-ray analysis, $\mathrm{CCDC}$ deposited [23]. ${ }^{\mathrm{d}}[19] .{ }^{\mathrm{e}}[20] . \mathrm{f}^{\mathrm{C}}[12]$. 
The products from the reaction of monofunctional ketones with ß-hydroperoxy alcohols $\mathbf{4}$ and 7 are collected in Table 1. All trioxanes $\mathbf{5 a}-\mathbf{e}$ derived from $\mathbf{4}$ were crystalline and could be analyzed by X-ray structure analysis (Figure 2). The bond lengths of the crucial O-O bond were similar in all cases with the exception of the adamantane derivative $5 \mathbf{d}$ which has a remarkably shorter O-O bond distance.

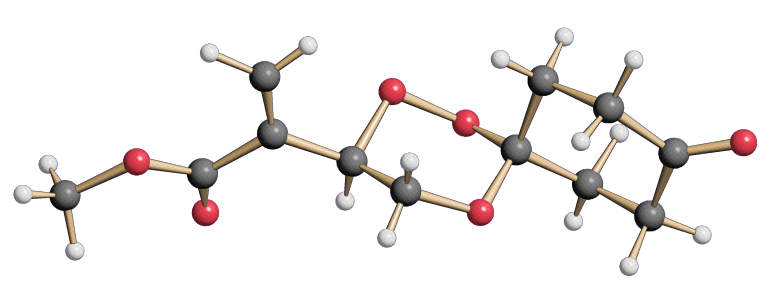

Figure 2: Structure of the spirobicyclic trioxane $5 c$ in the crystal.

\section{4-Arylated 1,2,4-trioxanes}

The 1,2,4-trioxanes $\mathbf{1 0}$ were formed in moderate to good yields, with the Hock-type cleavage product from the $\beta$-hydroperdiol as the only side-product, from 4 and substituted benzaldehydes under $\mathrm{BF}_{3}$-catalysis in $\mathrm{CH}_{2} \mathrm{Cl}_{2}$ solution (Scheme 3). In all cases the trans products were formed in high ( $>98: 2)$ diastereoselectivities. All compounds could be crystallized from acetone or from the neat liquid. In the crystal the central 1,2,4-trioxane ring is almost undistorted in a cyclohexane chair conformation with the acrylate and the aryl substituents in equatorial positions (Figure 3). In the crystal lattice the compounds, especially the 4-halophenyl-substituted trioxanes, tend to form $\pi$-stacked stabilized chain structures with channels that are filled with water molecules (Figure 4 ). In the elementary cell of the 4-chloro derivative 10c, an average of $320 \AA^{3}$ of channel space corresponds to one water molecules per trioxane molecule. By contrast, the 4-trifluormethyl derivative $\mathbf{1 0 f}$ crystallized in a compact chain-like package of anti-parallel arranged pairs of trioxanes.

The orientation of the aryl groups relative to the 1,2,4-trioxane equator depends largely on the nature of the para-substituent: in the phenyl-substituted trioxane 10a and in the para-halogenated analogs $\mathbf{1 0 b}-\mathbf{1 0 d}$, the aryl group is nearly coplanar with the $\mathrm{C}(3)-\mathrm{H}$ bond, whereas in the 4-nitro-, 4-trifluoromethyl-, and

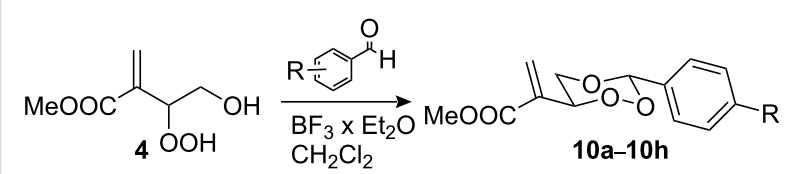

Scheme 3: $\mathrm{BF}_{3}$-catalyzed acetalization of hydroperoxide 4 with benzaIdehyde derivatives.

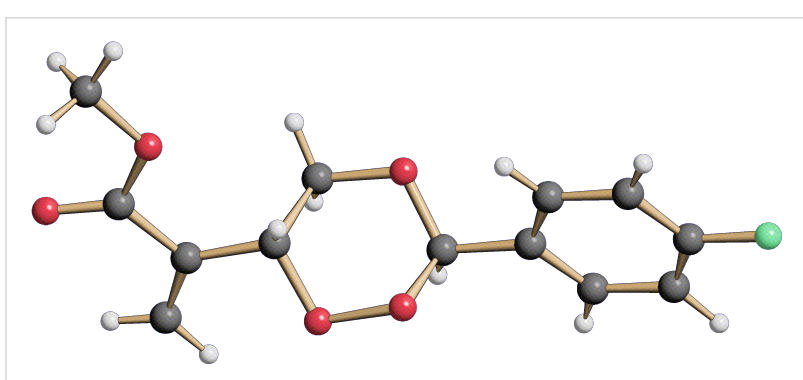

Figure 3: Structure of the 3-arylated trioxane $10 \mathrm{~b}$ in the crystal.

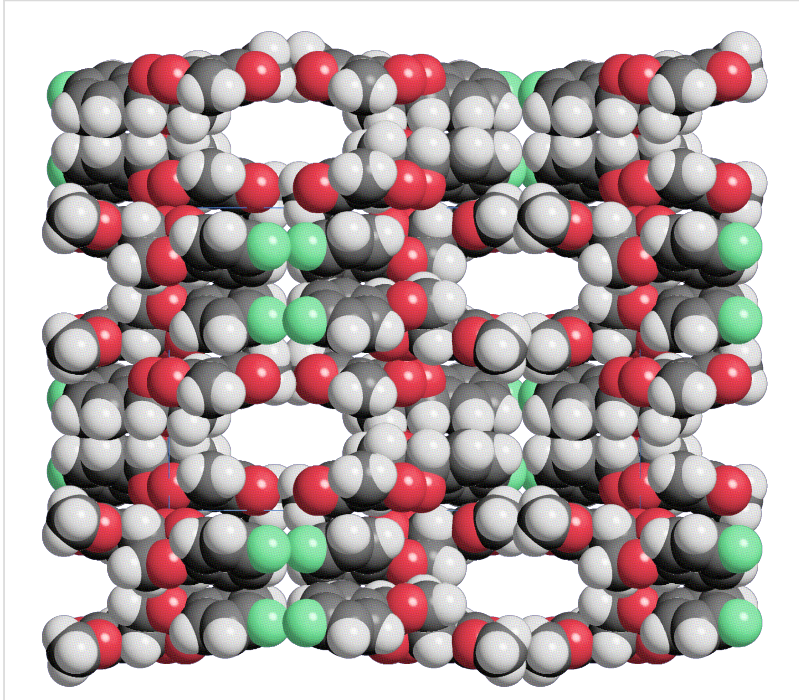

Figure 4: Structure of the p-bromophenyl derivative 10d in the crystal lattice (disordered water molecules in the cannels are not shown) viewed along the a axis.

4-cyano compounds $\mathbf{1 0 e}-\mathbf{1 0 f}$ coplanarity of the aryl substituent with the $\mathrm{O}(4)-\mathrm{C}(3)$ bond of the trioxane chair was observed (Table 2 and for numbering Figure 5).

In the artemisinin-derived arthemether (AM), the central trioxane ring has a twist-boat conformation resulting from the additional propylene bridge connecting C-3 and C-6. In Table 3 the yields of the peroxyacetalization reactions, the characteristic ${ }^{13} \mathrm{C}$ NMR shifts of the peracetal carbon C-3 and two significant bond lengths are listed. It is clear that the electronic nature of the substituent on the aryl group does not significantly change the bond length of the central peroxide bond (mean value: $1.479 \AA$ ). The mean value of the characteristic ${ }^{13} \mathrm{C}$ NMR shift of the peroxyacetal carbon C-3 is $103.4 \mathrm{ppm}$. The bond length of the central oxygen-oxygen bond in arthemether as determined by an independent structure analysis is $1.472(1) \AA$.

More pronounced bond lengths effects were observed for the O2-C3 ring bonds that range from 1.39 to $1.45 \AA$. Analysis of 


\begin{tabular}{|c|c|c|c|c|}
\hline 10 & $R=$ & $\Theta_{4-3-C(\text { ar/q) }-\mathrm{C}(\text { ar })}\left({ }^{\circ}\right)$ & $\Theta_{2-3-C(\operatorname{ar} / \mathrm{q})-\mathrm{C}(\operatorname{ar})}\left({ }^{\circ}\right)$ & $\Theta_{\mathrm{H}(\mathrm{C} 3)-3-\mathrm{C}(\mathrm{ar} / \mathrm{q})-\mathrm{C}(\mathrm{ar})}\left({ }^{\circ}\right)$ \\
\hline $10 a$ & $\mathrm{H}$ & 127 & 115 & 3 \\
\hline $10 \mathrm{~b}$ & $\mathrm{~F}$ & 142 & 100 & 19 \\
\hline $10 c$ & $\mathrm{Cl}$ & 141 & 101 & 18 \\
\hline $10 d$ & $\mathrm{Br}$ & 140 & 100 & 18 \\
\hline $10 \mathrm{e}$ & $\mathrm{NO}_{2}$ & 179 & 59 & 59 \\
\hline $10 f$ & $\mathrm{CF}_{3}$ & 154 & 90 & 26 \\
\hline $10 \mathrm{~g}$ & $\mathrm{CN}$ & 153 & 89 & 29 \\
\hline $10 \mathrm{~h}$ & $\mathrm{OMe}$ & 139 & 103 & 17 \\
\hline
\end{tabular}

asee [24] for CCDC submission.
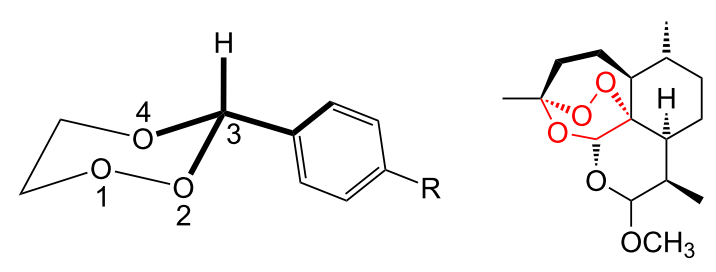

AM

Figure 5: Numbering of 3-aryl-1,2,4-trioxanes 10 and relevant bonds; structure of artemether (AM).

\begin{tabular}{|c|c|c|c|c|c|}
\hline 10 & $\mathrm{R}=$ & $\begin{array}{l}\text { yield } \\
(\%)^{a}\end{array}$ & $\begin{array}{l}\delta(C-3) \\
(p p m)^{b}\end{array}$ & 01-O2 (A) & O2-C3 (A) \\
\hline $10 a^{c}$ & $\mathrm{H}$ & 61 & 104.2 & $1.485(7)$ & $1.451(8)$ \\
\hline $10 b$ & $\mathrm{~F}$ & 40 & 103.5 & $1.472(3)$ & $1.432(3)$ \\
\hline $10 c$ & $\mathrm{Cl}$ & 35 & 103.4 & $1.474(3)$ & $1.425(4)$ \\
\hline $10 d$ & $\mathrm{Br}$ & 29 & 103.4 & $1.469(9)$ & $1.415(11)$ \\
\hline $10 e^{c}$ & $\mathrm{NO}_{2}$ & 31 & 102.6 & $1.471(9)$ & $1.398(11)$ \\
\hline $10 f$ & $\mathrm{CF}_{3}$ & 44 & 103.1 & $1.474(2)$ & $1.432(2)$ \\
\hline $10 \mathrm{~g}$ & $\mathrm{CN}$ & 38 & 102.7 & $1.4823(14)$ & $1.436(2)$ \\
\hline $10 \mathrm{~h}$ & OMe & 23 & 104.0 & $1.4806(19)$ & $1.438(2)$ \\
\hline AM & - & - & 102.9 & $1.472(1)$ & $1.416(3)$ \\
\hline
\end{tabular}

alsolated yield after purification by column chromatography. ${ }^{\mathrm{b}}$ In ppm, $75 \mathrm{MHz}$ in $\mathrm{CDCl}_{3}$. ${ }^{\mathrm{C}}$ Medium quality crystals, data not deposited.

the Cambridge crystallographic data file revealed that the mean oxygen-oxygen (O1-O2) bond distance for 1,2,4-trioxanes (108 compounds) is $1.472 \AA$ with a narrow distribution ranging from the extremes 1.460 ( 3 compounds) to 1.482 ( 4 compounds). All compounds $\mathbf{1 0 a}-\mathbf{h}$ investigated by us fall into this range, 10a,g,h showing the longest $\mathrm{O} 1-\mathrm{O} 2$ bond distances. With regards to antimalarial activity, all 4-arylated 1,2,4-trioxanes exhibited low in vitro activities $\left(\mathrm{EC}_{50} /\right.$ plasmodium falciparum $>$ $50 \mu \mathrm{M})$ with the nitro-substituted compound 10e as the most active derivative $\left(\mathrm{EC}_{50}=48 \mu \mathrm{M}\right)[25]$. Thus, the peroxide bond lengths do not correlate with biological activity, cf. the highly active $\mathbf{A M}$ and the fluoro compound $\mathbf{1 0 b}$.

\section{Conclusion}

In summary, we have reported the synthesis of a series of sixmembered ring 3,3-spiroannulated 1,2,4-trioxanes from methyl 4-hydroxytiglate and from mesitylol, respectively, by the singlet oxygen ene reaction and subsequent peroxyacetalization. A series of 4-arylated 1,2,4-trioxanes from methyl 4-hydroxytiglate was obtained by the same protocol. These compounds were fully characterized by spectroscopic methods and by X-ray structure determination.

\section{Experimental}

Synthesis of the 4-fluorophenyl derivative 10b: A solution of $290 \mathrm{mg}(2.0 \mathrm{mmol})$ of the hydroperoxide 4 (prepared from methyl 4-hydroxytiglate (3) by the method described in [10]) and $220 \mathrm{mg}(2.0 \mathrm{mmol})$ of 4-fluorobenzaldehyde in $40 \mathrm{ml}$ of dichloromethane was treated at $0{ }^{\circ} \mathrm{C}$ with $0.2 \mathrm{ml}$ of boron trifluoride in diethyl ether. After stirring overnight at room temperature, the solution was diluted to $100 \mathrm{ml}$ with dichloromethane, washed successively with $20 \mathrm{ml}$ of saturated aqueous sodium bicarbonate solution, brine and water. The organic phase was separated and dried. After evaporation and column chromatography (silica, EtOAc), $200 \mathrm{mg}$ (40\%) of $\mathbf{1 0 b}$ was obrained as a colorless viscous oil that crystallized as thin plates on standing: $\mathrm{C}_{13} \mathrm{H}_{15} \mathrm{FO}_{6}$ (corresponds to $\mathrm{C}_{13} \mathrm{H}_{13} \mathrm{FO}_{5} \times \mathrm{H}_{2} \mathrm{O}$ : colorless thin needles from aqueous acetone), $M=286.25, a=6.1264(3), b=$ 16.8514(9), $c=26.2519(14), \alpha, \beta, \gamma=90^{\circ}$, orthorhombic, space group Pnaa, Mo-K $\mathrm{K}_{\alpha}, 15276$ reflections measured, 2948 reflections with $I>2 \sigma(I), R_{1}$ (all data) $=0.0573, w R_{2}=0.1811$.

\section{Acknowledgements}

We thank the DFG for project funding and the University of Cologne for a start-up grant. Biological testing was performed in South-Korea. AGG is recipient of the 2009 Honda-Fujishima award (Asian Photochemistry Association) for the antimalarial trioxane research. 


\section{References}

1. Klayman, D. L. Science 1985, 228, 1049-1055. doi:10.1126/science.3887571

2. O'Neill, P. M.; Posner, G. H. J. Med. Chem. 2004, 47, 2945-2964. doi:10.1021/jm030571c

3. Zhou, W. S.; Xu, X. X. Acc. Chem. Res. 1994, 27, 211-216. doi:10.1021/ar00043a005

4. Robert, A.; Dechy-Cabaret, O.; Cazelles, J.; Meunier, B. Acc. Chem. Res. 2002, 35, 167-174. doi:10.1021/ar990164o

5. Meunier, B. Acc. Chem. Res. 2008, 41, 69-77. doi:10.1021/ar7000843

6. Efferth, T.; Romero, M. R.; Wolf, D. G.; Marin, J. J. G.; Marschall, M. Clin. Infect. Dis. 2008, 47, 804-811. doi:10.1086/591195

7. Efferth, T. Curr. Drug Targets 2006, 7, 407-421. doi:10.2174/138945006776359412

8. Maude, R. J.; Pontavornpinyo, W.; Saralamba, S.; Aguas, R.; Yeung, S.; Dondorp, A. M.; Day, N. P. J.; White, N. J.; White, L. J. Malaria J. 2009, 8, No. 31. doi:10.1186/1475-2875-8-31

9. Tang, Y.; Dong, Y.; Vennerstrom, J. L. Med. Res. Rev. 2004, 24, 425-448. doi:10.1002/med.10066

10. Rydén, A.-M.; Kayser, O. Chemistry, Biosynthesis and Biological Activity of Artemisinin and Related Natural Peroxides. In Bioactive Heterocycles III; Gupta, R. R., Ed.; Topics in Heterocyclic Chemistry, Vol. 9; Springer: Berlin, 2007; pp 1-31. doi:10.1007/7081_2007_085

11. Bartoschek, A.; El-Idreesy, T. T.; Griesbeck, A. G.; Höinck, L.-O.; Lex, J.; Miara, C.; Neudörfl, J. M. Synthesis 2005, 2433-2444.

12. Griesbeck, A. G.; El-Idreesy, T. T.; Höinck, L.-O.; Lex, J.; Brun, R. Bioorg. Med. Chem. Lett. 2005, 15, 595-597. doi:10.1016/j.bmcl.2004.11.043

13. Vennerstrom, J. L.; Arbe-Barnes, S.; Brun, R.; Charman, S. A.; Chiu, F. C. K.; Chollet, J.; Dong, Y. X.; Dorn, A.; Hunziker, D.; Matile, H.; Mclntosh, K.; Padmanilayam, M.; Tomas, J. S.; Scheurer, C.; Scorneaux, B.; Tang, Y. Q.; Urwyler, H.; Wittlin, S.; Charman, W. N. Nature 2004, 430, 900-904. doi:10.1038/nature02779

14. Ellis, G. L.; Amewu, R.; Sabbani, S.; Stocks, P. A.; Shone, A.; Stanford, D.; Gibbons, P.; Davies, J.; Vivas, L.; Charnaud, S.; Bongard, E.; Hall, C.; Rimmer, K.; Lozanom, S.; Jesús, M.; Gargallo, D.; Ward, S. A.; O'Neill, P. M. J. Med. Chem. 2008, 51, 2170-2177. doi:10.1021/jm701435h

15. Miyazaki, A.; Tsuda, Y.; Fukushima, S.; Yokoi, T.; Vántus, T.; Bökönyi, G.; Szabó, E.; Horváth, A.; Kéri, G.; Okada, Y. J. Med. Chem. 2008, 51, 5121-5124. doi:10.1021/jm701599w

16. Furber, M.; Alcaraz, L.; Bent, J. E.; Beyerbach, A.; Bowers, K.; Braddock, M.; Caffrey, M. V.; Cladingboel, D.; Collington, J.; Donald, D. K.; Fagura, M.; Ince, F.; Kinchin, E. C.; Laurent, C.; Lawson, M.; Luker, T. J.; Mortimore, M. M. P.; Pimm, A. D.; Riley, R. J.; Roberts, N.; Robertson, M.; Theaker, J.; Thorne, P. V.; Weaver, R.; Webborn, P.; Willis, P. J. Med. Chem. 2007, 50, 5882-5885. doi:10.1021/jm700949w

17. Singh, C.; Kanchan, R.; Sharma, U.; Puri, S. K. J. Med. Chem. 2007, 50, 521-527. doi:10.1021/jm0610043

18. Griesbeck, A. G.; Bartoschek, A. Chem. Commun. 2002, 1594-1595. doi:10.1039/b204017d

19. Griesbeck, A. G.; El-ldreesy, T. T.; Bartoschek, A. Adv. Synth. Catal. 2004, 346, 245-251. doi:10.1002/adsc.200303181

20. Griesbeck, A. G.; Höinck, L.-O.; Lex, J. Lett. Org. Chem. 2006, 3, 247-249. doi:10.2174/157017806775789903

21. Griesbeck, A. G.; El-Idreesy, T.; Fiege, M.; Brun, R. Org. Lett. 2002, 4, 4193-4195. doi:10.1021/ol026916n
22. Griesbeck, A. G.; Höinck, L.-O.; Lex, J.; Neudörfl, J.; Blunk, D.; El-Idreesy, T. T. Molecules 2008, 13, 1743-1758. doi:10.3390/molecules13081743

23. The crystallographic data for the 3,3-spiroannulated 1,2,4-trioxanes $\mathbf{5 b}$, $\mathbf{5 c}$, and $\mathbf{5 e}$ have been deposited with the Cambridge Crystallographic Data Centre as supplementary publications no. CCDC-776052 (5b), CCDC-776053 (5c), CCDC-775054 (5e).

24. The crystallographic data for the 3-arylated trioxanes $10 \mathrm{~b}-\mathbf{d}$ and $\mathbf{1 0 f}-\mathbf{h}$ have been deposited with the Cambridge Crystallographic Data Centre as supplementary publications no. CCDC-762733 (10b), CCDC-762734 (10c), CCDC-762735 (10d), CCDC-762736 (10f), CCDC-762737 (10g), CCDC-762738 (10h)

25. Griesbeck, A. G.; Brodwolf, A.; Höinck, L.-O.; El-Idreesy, T. T.; Kim, H.-S. unpublished results.

\section{License and Terms}

This is an Open Access article under the terms of the Creative Commons Attribution License (http://creativecommons.org/licenses/by/2.0), which permits unrestricted use, distribution, and reproduction in any medium, provided the original work is properly cited.

The license is subject to the Beilstein Journal of Organic Chemistry terms and conditions: (http://www.beilstein-journals.org/bjoc)

The definitive version of this article is the electronic one which can be found at: doi:10.3762/bjoc.6.61 